\title{
Proteinase-Activated Receptor 4
}

National Cancer Institute

\section{Source}

National Cancer Institute. Proteinase-Activated Receptor 4. NCI Thesaurus. Code C102544.

Proteinase-activated receptor 4 ( $385 \mathrm{aa}, \sim 41 \mathrm{kDa}$ ) is encoded by the human F2RL3 gene. This protein plays a role in both the mediation of receptor signaling and the promotion of platelet activation. 